\title{
Entry Flow of Polymer Solutions through Multi-hole Abrupt Contractions
}

\author{
Yuichi NAKA $^{* 1}$, Kunji CHIBA ${ }^{* 2}$, Kiyoji NAKAMURA ${ }^{* 1}$ \\ ${ }^{*}$ Department of Mechanophysics Engineering, Graduate School of Engineering, \\ Osaka University, Suita, Osaka 565-0871, Japan \\ ${ }^{* 2}$ Faculty of Education, Shiga University, \\ Otsu, Siga 520-0862, Japan
}

\begin{abstract}
Flow visualizations and velocity measurements for entry flows of shear-thinning aqueous solutions of polyacrylamide through three kinds of multi-hole contractions have been carried out using the tracer method and LDV technique. In these experiments effects of the number of contractions, distance between contractions and rheology of solutions on the flow structures have been studied. For the multi-hole contractions square arrays of 9 holes and 25 holes were used. In the steady flow regime dimensionless lip vortex length is almost the same for all multi-hole contractions. Swirling-like vortices are also observed for both three-by-three and five-by-five contractions with dimensionless pitch 4 , while two-dimensional lip vortices are observed for the three-by-three contraction with dimensionless pitch 8. It is found from LDV measurements that periodic oscillations of the main flow occur at the onset of unsteady flow for all multi-hole contractions and the frequency of the oscillation increases as the Weissenberg number increases. For multi-hole contractions, flow interaction through each contraction is very important factor which decides both steady and unsteady flow structures.
\end{abstract}

Key Words: Multi-hole contraction / Flow visualization / LDV measurement / Polymer solution / Lip vortex

\section{多数の円孔急縮小部を有する流路における高分子溶液の流れ

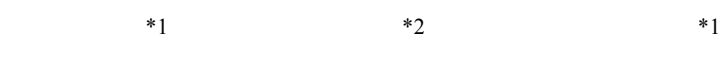

(原稿受理: 1998 年 7 月 7 日)

\section{1. 緒 言}

高分子流体は, 水や Glycerin などのニュート流体とは著しく 異なる性質を有する.一つはせん断速度により粘度が変化する 非ニュート粘性を示すことであり,もう一つは跳ね戻り現象など に見られるような弾性的性質を有することである。

高分子物質の射出成形加工や紡系工程では,樣々な形状の 流路が用いられるが,急縮小形状の流路内での流れが製品の 品質に大き影響を与える場合がよく見られる.従って流路の効 率的な設計を行うために，急縮小部での流れの機構を知ること

\footnotetext{
${ }^{* 1}$ 大阪大学大学院工学研究科 $\bar{T} 565-0871$ 大阪府吹田市山田丘 2-1

*2 滋賀大学教育学部 $=520-0862$ 滋賀県大津市平津 2-5-1
}

は非常に重要である.

高分子溶液や融液などの粘弾性流体が,急縮小流路を流れ るとき,収縮管の上流角部に循環 2次流れが発生することがよく 知られている.流量増加にともな渦の発生, 成長については, 多くの研究がある.光れらのうち慣性力が支配的な流れでは渦 がささなった後, 非定常流へと遷移し, 粘弾性的な力に支配 される流れでは渦の成長後, 非定常流れを引き起こすと報告さ れている(1) 3) .渦発生の原因として,Cable と Boger ${ }^{4) \sim 6) ~}$ は第一法線応力差に代表されるせん断特性を挙げている. 一方，White とKondo ${ }^{7)}$,White とBaird ${ }^{8)}$ は LDPE およびPS 融 液について伸長応力の過渡的な成長過程を調べ,伸長応力の 


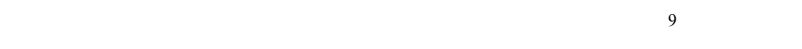
度の stretch-thickening 性と渦の増大について言及している.方,Bulters $ら^{10)}$ は循環 2 次流れの大きさがDeborah 数の関数で あることを示し,また Evans ら ${ }^{11}$ は管入口の角部に発生する lip vortex が循環 2次流れの成長に大きな影響を及ぼすことを報告 している.さらに流れの变動を定量的に調べた報告も多い Lawler ら ${ }^{12)}$ はレーザードップラー流速計による流速測定により， 非定常流への臨界 Deborah 数を見出した .また,McKinley $ら^{131}$ は lip vortex 付近の流速変動により,定常流から非定常流まで を5つの領域(steady, periodic, period doubling, quasi-periodic, aperiodic)に分類している.

このように,急縮小流路の流れについての研究は数多くなさ れているが,光のほとんどは軸対称の円管流路や矩形管流路内 の流れを取り䏜ったものである.現在までにこれら以外の流路を 取䏜った研究報告は少なく,上流管と下流管との中心軸を偏 心させた流路を取 (䏜った中村ら $\left.{ }^{14}\right)$ や中 ${ }^{15}$ ), 複数の急縮小部

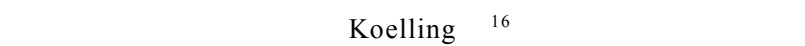
程度である.しかし現在, 成形加工や紡系工程において, 複数 の急縮小部を有する流路が頻繁に使われており,このような流 路における流れ構造を知ることが重要になっている.弚こで本研 究では,多数の円孔急縮小部を有する流路を使用し,产れら縮 小管の個数や縮小管の間隔を变化させた時の流れ構造の違い を調べた 。

\section{2. 試料流体について}

\section{$2 \square 1$ 試料流体の特性}

本研究では, 高分子溶液として polyacrylamide 商品名 SANFLOC-AH70P，三洋化成工業製，以下 PAA と略記する)の 0.2 ，および $0.5 \mathrm{wt} \%$ 水溶液を用いた .液温 $20^{\circ} \mathrm{C} て ゙$ 測定した試料 流体のレオロジー特性を図 1に示す.これより明らかなように， PAA 水溶液はせん断速度が増加するとせん断粘度が減少する (shear-thinning 性)とともに第一法線応力差は増大する.

\section{$2 \square 2$ 流動状態を表すパラメータ}

本研究では,実験時のせん断速度を式(1)のように下流管の平 均せん断速度 $\dot{\gamma}_{d}$ で代表する。

$$
\dot{\gamma}_{d}=\left\langle v_{z}\right\rangle_{d} / R_{d}
$$

ただし, $\left\langle v_{z}\right\rangle_{d}$ は下流管平均流速， $R_{d}$ は下流管半径である.

実験はすべて $25^{\circ} \mathrm{C}$ の液温で行ったため，実験時のレオロジ 一特性值を求めるには温度補正が必要である.温度補正の方 法については既報3115)で詳し〈説明しているのでここでは省略す る.一方，せん断応力 $\tau$ と第一法線応力差 $N_{1}$ の関係は温度に

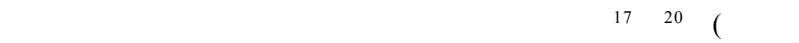
照).乥こで実験時の第一法線応力差は実験時のせん断応力を

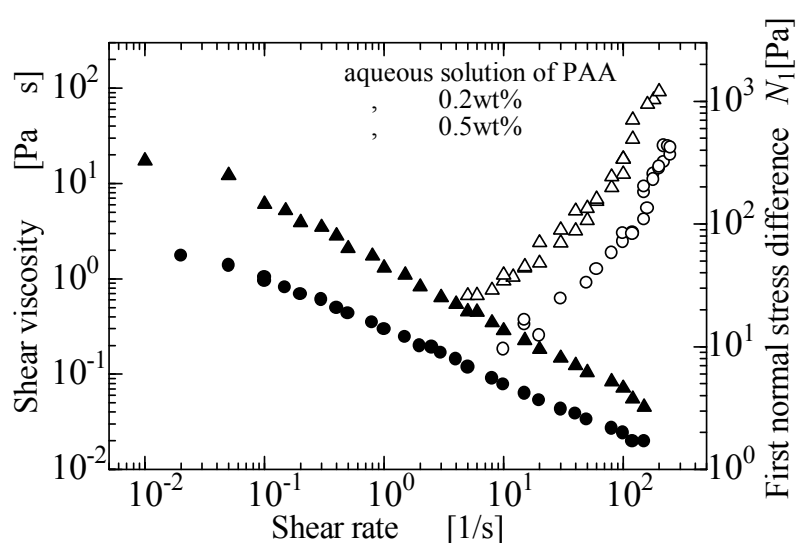

Fig.1 Rheometrical data for the aqueous solutions of PAA at $20^{\circ} \mathrm{C}$. Solid symbols $(\mathbf{A})$; shear viscosity and hollow symbols $(\bigcirc \triangle)$; first normal stress difference.

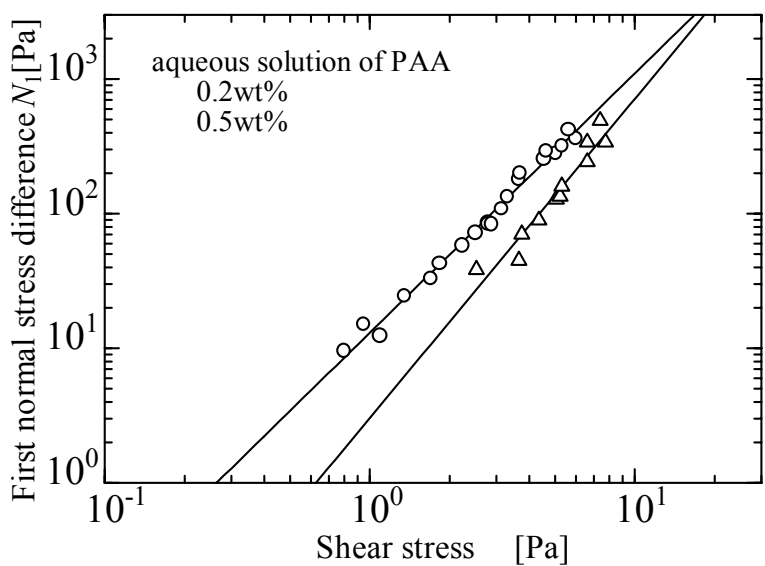

Fig.2 First normal stress difference as a function of shear stress for the aqueous solutions of PAA at $20^{\circ} \mathrm{C}$.

用いて求め,緩和時間入は式(2)により算出する。

$$
\lambda=\frac{N_{1}}{2 \tau \cdot \dot{\gamma}_{d}}
$$

本研究では流動状態を示すパラメータにレイノルズ数および ワイセンベルク数を用いる.

$$
\begin{aligned}
& R e=\frac{\rho \cdot\left\langle v_{z}\right\rangle_{d} \cdot 2 R_{d}}{\eta} \\
& W e=\frac{\lambda \cdot\left\langle v_{z}\right\rangle_{d}}{2 R_{d}}
\end{aligned}
$$

\section{3. 実験装置および実験方法}

本研究では流れ模樣を調べるために固体トーサー法による 可視化実験を行い，また流速測定にはレーザードップラー流速 計(以下 LDV と略記する)を使用した .

本研究では可視化実験およびLDVによる流速測定で図 3 に 示すよ汭流路を使用した.図 3 において Head tank から Test sectionに流入する試料流体は，縮小部の十分上流ですでに発 


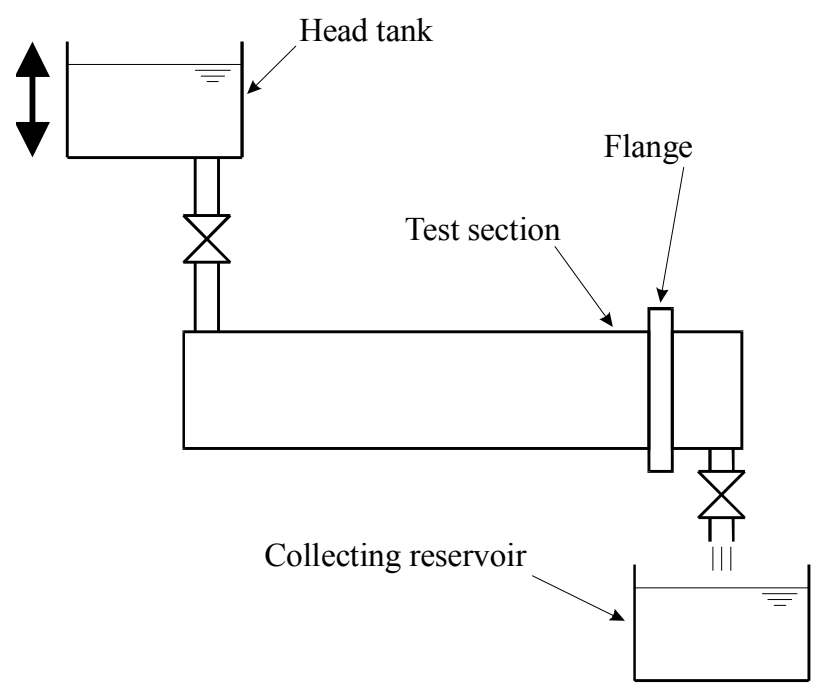

Fig.3 Schematic diagram of the experimental apparatus.

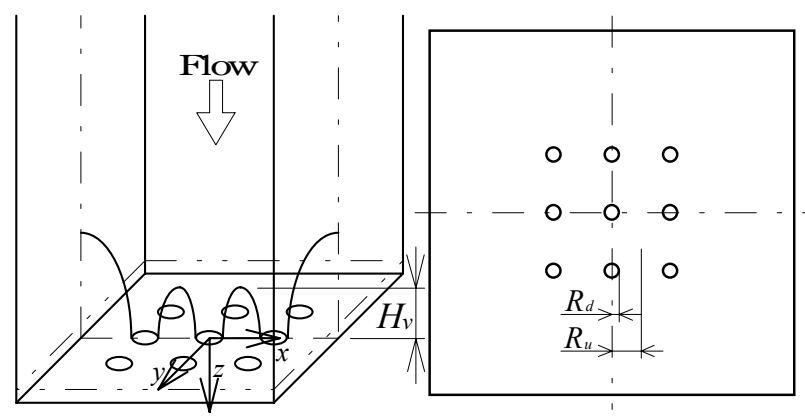

Fig.4 Schematic diagram of the contraction geometry and observation planes.

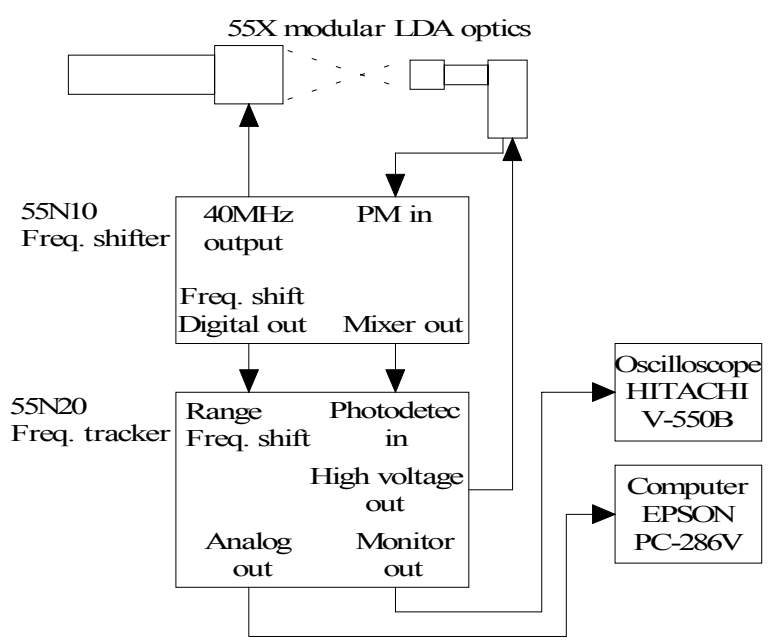

Fig.5 Schematic diagram of the laser-Doppler velocimetry system.

達した流れとなっている.また縮小部はフランジを介して取り付け ることにより,複数の流路に対応するように設計されている.流量 は出口部を固定し,Head tank を上下に移動させることによ颜 節している。
急縮小部の概略を図 4 に示す.本研究では各方向からの流 れの観察を可能にするため上流管には一辺 $100 \mathrm{~mm}$ の矩形管を 採用した.縮小管は半径 $2 \mathrm{~mm}$ の円孔で図 4 のよう 9 個正方 形に配列したものと,25 個配列したものを使用した.比較のため 中心部に 1 個だけ配置したものも用意した.本研究ではすべて の流路で上流管と縮小管の形状を固定し, 図に示すよう円孔 の半径 $R_{d}$ と円孔間の中心間距離の半分 $R_{u}$ との比 $R_{u} / R_{d}$ およ び縮小管数で流路を特徵付ける.この $R_{d}$ と $R_{u}$ との比 $R_{u} / R_{d}$ を 無次元ピツチと定義する.また $R_{u}: R_{d}$ は Koelling $ら^{16)}$ の実験に おけるcontraction ratio に相当する。

\section{1 可視化実験}

本研究では可視化実験に固体ルーサー法を採用した.固体 トーサー法では, 直径 $0.1 \mathrm{~mm}$ 以下の polystyrene 粒子を溶液 に約 $0.025 \mathrm{wt} \%$ 混入した.スリッ恍は厚さ約 $1 \mathrm{~mm}$ で,図 4 に示 す上流管中心軸を含む 1 点鎖線の断面および縮小面と平行な 2 点鎖線の断面に入射した.流れ模樣はカメラ(Nikon FM2)を 使用して撮影した .カメラの露光時間はトーサーがファインダ 一内を通過する時間を基準にし, 流動状態によって決定した .

\section{$3 \square 2$ LDV による流速測定}

本研究で使用した LDV 測定装置は図 5 に示すように 2 本の レーザーの交差部を photomultiplier で検出する 1 次元前方散

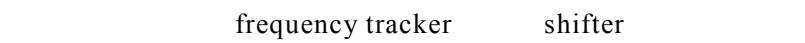
DISA $55 \mathrm{~N} 20,55 \mathrm{~N} 10$ を使用し,これによ得られた電気信号を A/D 変換ボード(Canopus ADJ-98)を介してコンピュータで流速 データに換算した .また得られた流速データは高速 Fourier 変換 し21),速度変動も同時に調べた。

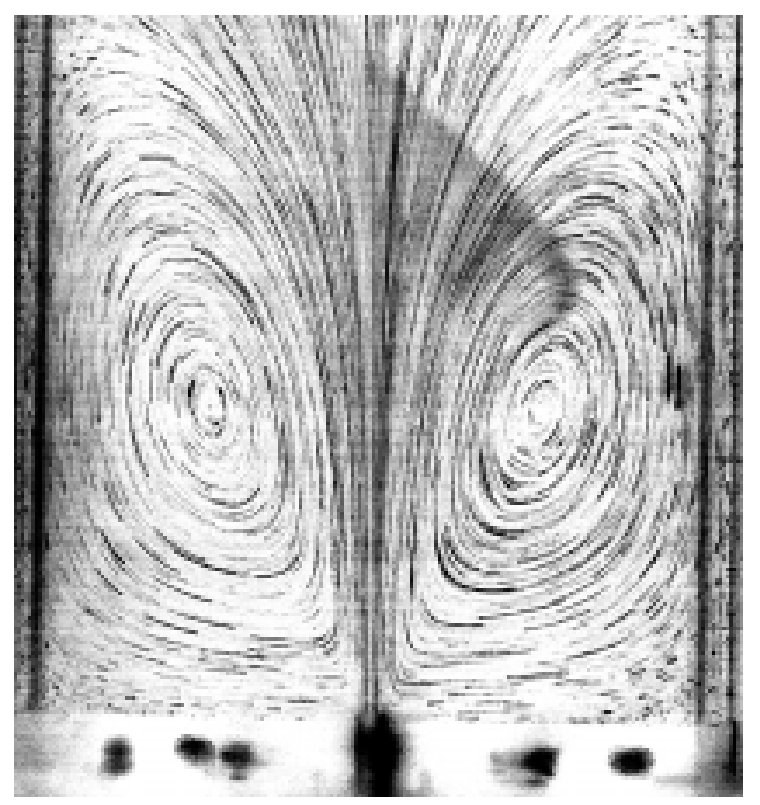

Fig.6 Flow patterns for the $0.2 \mathrm{wt} \%$ aqueous solution of PAA through a single-hole contraction; $R e=1.36, W e=2.88$. 


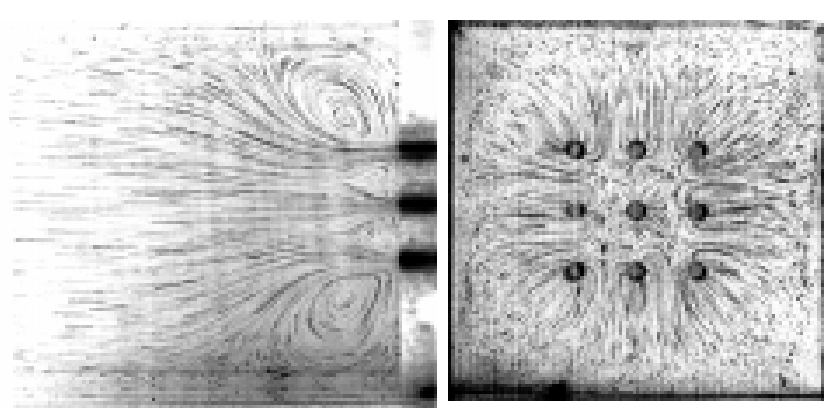

Fig.7 Flow patterns for the $0.2 \mathrm{wt} \%$ aqueous solution of PAA through a multi-hole three-by-three contraction (dimensionless pitch 4); $R e=0.309, W e=1.89$.

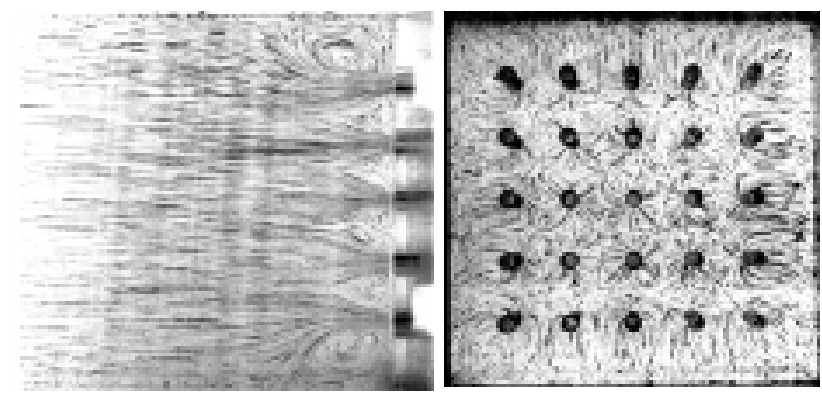

Fig.8 Flow patterns for the $0.2 \mathrm{wt} \%$ aqueous solution of PAA through a multi-hole five-by-five contraction (dimensionless pitch 4); $R e=0.103, W e=1.39$.

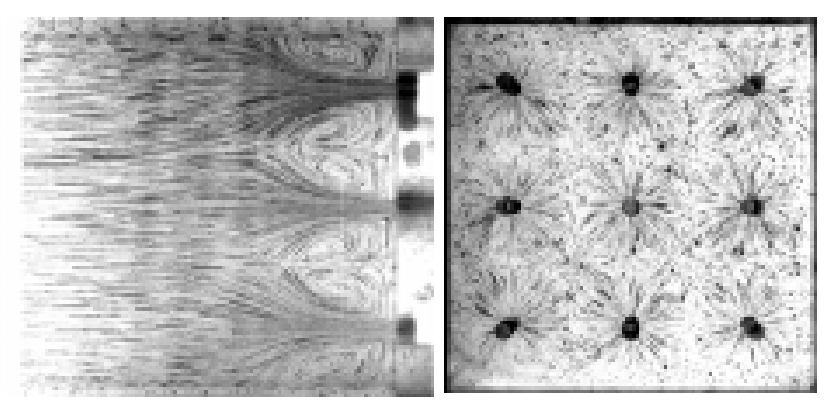

Fig.9 Flow patterns for the $0.2 \mathrm{wt} \%$ aqueous solution of PAA through a multi-hole three-by-three contraction (dimensionless pitch 8); $R e=0.343, W e=1.92$.

\section{4. 実験結果}

本研究では, 定常流から非定常流に遷移するレイノルズ数， ワイセンベルク数を光れ臨界レイノルズ数,臨界ワイセンベ ルク数と称し,これらの判断は撮影した流跡に交錯が見られるか 否かによって行う.

\section{1 定常流}

\section{1 流れ構造}

図 6 は中央に 1 個だけ円孔を配置した流路における流れ模樣 である.主流のまわりに粘弾性流体特有の大きな渦, secondary vortexが発生しているのが分かる.この実験条件の場合，Re=2， $W e=3$ を越えないと非定常流へは遷移しない.

図 7 は無次元ピッチ 4 ,縮小管数 9 の流路における撮影結果
である.左側が中央の縮小管中心軸を含む図 4 の 1 点鎖線の 断面，右側が縮小面近傍の 2 点鎖線の断面である.縮小管と上 流管壁面との間に，下流側に尖った secondary vortex が観察さ れる.この渦と主流との境界に注目すると, 渦内の流跡が主流 側に入り縮小管へ流出している樣子が見られる.すなわち secondary vortex と主流とは完全には閉じていない.また各縮小 管の間の lip vortex は巻き込んでいるように見えるが,これは渦 が3次元流れであるために観察されるものと考えられる.さらに图 7 の縮小面近傍での撮影結果では,縮小管のまわりの状況に応 じて ,渦を 3 つのパターンに大別することができる.まずまわりを すべてほかの縮小管に取 (囲まれた中心の縮小管の場合，縮 小管のまわりに 4 つのブロックに分類された lip vortex が発生す る.まわりに上流管の隅がある角の縮小管の場合，縮小管を取 り囲むように secondary vortex が存在する.乥して外側に流路壁 面がある縮小管の場合は細長い secondary vortex となる.

図 8 は円孔をさらに外側に 1 列配置した無次元ピッチ 4 ,縮小 管数 25 の流路における撮影結果である.中央の 3 列の縮小管 では無次元ピッチ 4 ,縮小管数 9 (図 7)の流路における中心の 縮小管と同樣の流れ構造が観察される.したがって, 仮にさらに 外側に縮小管数を増やしたとしても，同樣の流れ構造が続くも のと考えられる.

図 9 は無次元ピッチ 8 ,縮小管数 9 の流路における撮影結果 である.縮小管の間の lip vortexは,他の流路と異なり,巻き込 んだ渦にはならない.また縮小面近傍の撮影結果から,各縮小 管のまわりの渦が均等に配置しており,縮小管の間での流れの 相互干渉は極めて小さいことがわかる.

図 6〜9はすべて $0.2 \mathrm{wt} \% \mathrm{PAA}$ 水溶液を用いた可視化実験結 果である. $0.5 \mathrm{wt} \% \mathrm{PAA}$ 水溶液についても実験を行ったが, 同樣 の流れ構造か観察された .

\section{$4 \square 1 \square 2$ 縮小管の間に発生する lip vortex}

図 10 は各濃度の溶液の可視化実験から,縮小管の間に発 生するlip vortex の大きさを示したグラフである.渦の大きさは図 4 における $H_{v}$ を計測し,弚れを縮小管の中心間距離 $2 R_{u}$ で割つ た無次元量 $\left(\chi \equiv H_{v} / 2 R_{u}\right)$ で表している.また無次元ピッチ 4 ， 縮小管数 9 および無次元ピツチ 4 ,縮小管数 25 の両流路にお ける $0.2 \mathrm{wt} \% \mathrm{PAA}$ 水溶液での実験については非定常流の初期 では lip vortex の大きさに乥れほと変動がなかったので,この領 域まで計測を行った

$0.2 \mathrm{wt} \% \mathrm{PAA}$ 水溶液ではすべての流路において, 非定常流 遷移直前から非定常流初期にかけて光れまでよりも渦が大きく 増大していることが分かる. $0.5 \mathrm{wt} \% \mathrm{PAA}$ 水溶液については产の ような現象は見られないが, $0.5 \mathrm{wt} \% \mathrm{PAA}$ 水溶液の場合，どの流 路でも非定常流に遷移するとすぐに流れ全体が乱れ渦高さが 計測できなかったため，現時点ではこの現象が $0.2 \mathrm{wt} \% \mathrm{PAA}$ 水 溶液特有のものと断言することはできない.この現象を除けば， 全体的に流路形状や溶液の濃度の違いによる渦の大きさの差 


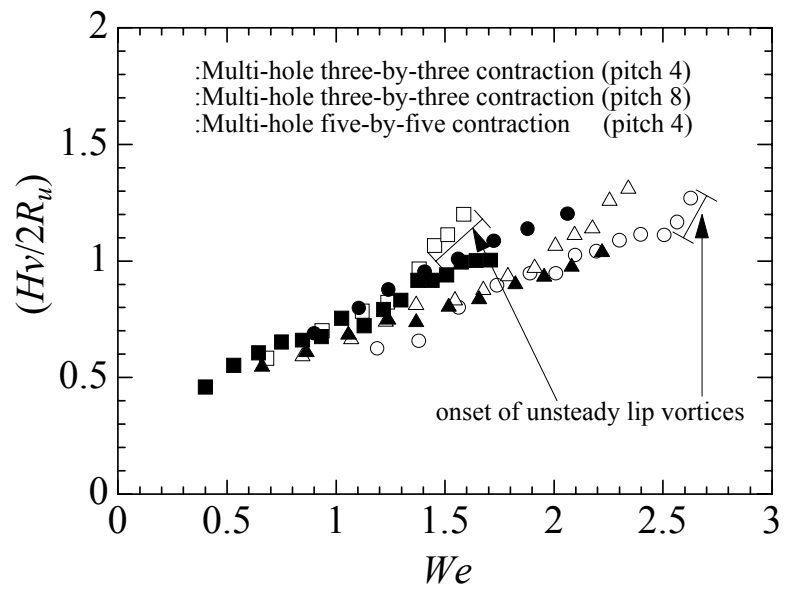

Fig.10 Lip vortex length $X$ as a function of Weissenberg number. Hollow symbols $(\bigcirc \triangle \square) ; 0.2 \mathrm{wt} \%$ aqueous solution of PAA and solid symbols $(\mathbf{O} \mathbf{\Delta}) ; 0.5 \mathrm{wt} \%$ aqueous solution of PAA.

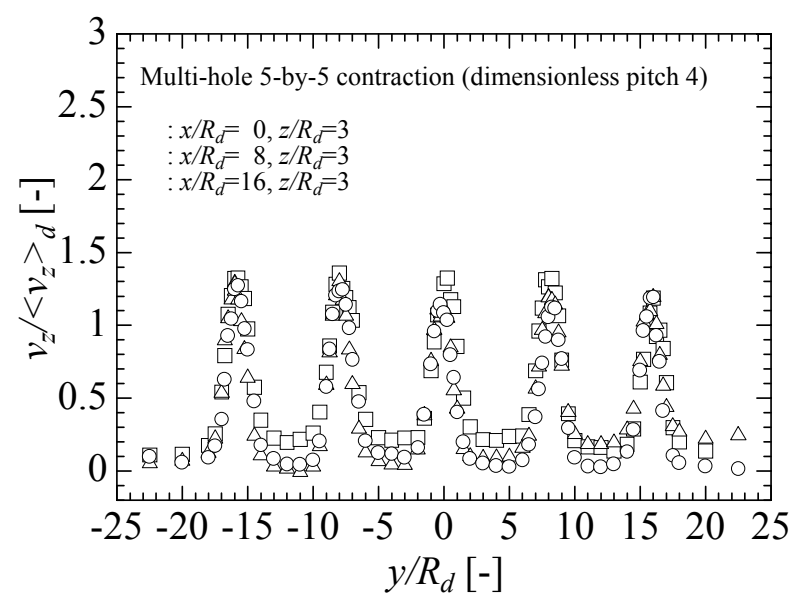

Fig.11 Dimensionless axial velocity profiles along the y-axis for the $0.2 \mathrm{wt} \%$ aqueous solution of PAA through a multi-hole five-byfive contraction (dimensionless pitch 4); $R e=0.0626, W e=1.21$.

Table. I Critical Reynolds and Weissenberg numbers for the multi-hole contractions and aqueous solutions of PAA.

\begin{tabular}{|c|c|c|c|}
\hline contraction & $\begin{array}{l}\text { three-by-three } \\
\text { pitch } 4\end{array}$ & $\begin{array}{l}\text { five-by-five } \\
\text { pitch } 4\end{array}$ & $\begin{array}{l}\text { three-by-three } \\
\text { pitch } 8\end{array}$ \\
\hline $0.2 \mathrm{wt} \% \mathrm{PAA}$ & $\begin{array}{c}R e \\
0.58 \sim 0.80 \\
W e \\
2.2 \sim 2.4\end{array}$ & $\begin{array}{c}R e \\
0.10 \sim 0.13 \\
W e \\
1.4 \sim 1.5 \\
\end{array}$ & $\begin{array}{c}R e \\
0.60 \sim 0.82 \\
W e \\
2.2 \sim 2.4\end{array}$ \\
\hline $0.5 \mathrm{wt} \% \mathrm{PAA}$ & $\begin{array}{c}R e \\
0.049 \sim 0.064 \\
W e \\
2.0 \sim 2.2\end{array}$ & $\begin{array}{c}R e \\
0.02 \stackrel{3 \sim 0.029}{W} \\
W e \\
1.6 \sim 1.8\end{array}$ & $\begin{array}{c}R e \\
0.044 \sim 0.066 \\
W e \\
2.0 \sim 2.2\end{array}$ \\
\hline
\end{tabular}

は光れほどなく,すなわち lip vortex の大きさが流路形状や溶液 のレオロジー特性にはあまり影響されず，ワイセンベルク数によ って決まることを示す.この結果は中ら $\left.{ }^{15}\right)$ が行った偏心流路にお ける実験結果と定性的に一致する。

\section{3 流速分布}

図 11 は無次元ピッチ 4 ,縮小管数 25 の流路における $y$ 軸方
向の速度分布である.流速はLDVにより測定し,下流管平均流 速 $\left\langle v_{z}\right\rangle_{d}$ で割った無次元量 $v_{z} /\left\langle v_{z}\right\rangle_{d}$ で表している.また図に 示している $x / R_{d}$ は各列の縮小管の中心軸を通るように選定し， 縮小面近傍の $z / R_{d}=3$ を採用した.LDV による流速測定では すべて $0.2 \mathrm{wt} \% \mathrm{PAA}$ 水溶液を使用した .

图 11 よりすべての縮小管にほぼ同じ流速で主流が流出して いることが分かる.他の流路についても測定を行い, 同樣の結果 になることが確認された.したがって, 本研究のような多数の縮小 管を持つ流路内の定常流においては, 流体は乥れ光れの縮小 管にほぼ同程度の流量で流出するものと考えられる。

\section{$4 \square 2$ 定常流から非定常流への遷移}

\section{$402 \square 1$ 臨界レイノルズ数および臨界ワイセンベルグ数}

可視化実験における撮影結果から流跡の交錯を調べ, 表 । に臨界レイノルズ数, 臨界ワイセンベルク数を示す.実験ごとに 多少変化するため,表の值には幅を持たせている.すべての流 路, 溶液において臨界レイノルス数は $R e<1$ であり,すなわち本 研究のような実験条件の場合,慣性の影響が小さい領域ですで に非定常流へ遷移することが分かる.すなわち, 非定常流への 遷移は慣性によって生ずるのではなく,せん断流れと伸長流れ の混在による複雑な流れに起因するものと考えられる.また縮小 管数 25 の流路の方が縮小管数 9 の流路より低い值で非定常流 へ遷移している.さらに縮小管数 9 の流路では無次元ピツチに かかわらずほぼ同じ值になっている.したがって, 臨界值は縮小 管数と溶液のレオロジー特性に依存して決まり, 縮小管数が多 いほど小さくなる.

\section{$402 \square 2$ 流れ構造}

無次元ピッチ 4 ,縮小管数 9 の流路および縮小管数 25 の流 路では, 渦が成長した後, 表 $の$ 臨界点に達すると非定常流へ 遷移する.しかし無次元ピッチ 8 ,縮小管数 9 の流路については， 単純に渦か増大することはなく,他の流路と異なった流れ構造を 示す.ごく低流量から次第に流量を増大させると, $0.2 \mathrm{wt} \% \mathrm{PAA}$ 水溶液の場合, $R e=0.33, W e=1.9$ を越えたあたりから縮小管の 間にある一対の lip vortex の渦中心の位置が軸方向にずれ始 める(図 12(a)) $.0 .5 \mathrm{wt} \% \mathrm{PAA}$ 水溶液では $R e=0.011, W e=1.4$ あた 价らの現象が見られ, $0.2 \mathrm{wt} \% \mathrm{PAA}$ 水溶液の場合と比較する とかなけ小さい.さらに流量を上げるとこの現象は顕著になり, 図 12(b)のように片方の lip vortex が崩れかけるような樣子を示した 後, 非定常流入遷移する. 非定常流に遷移しても光の直後, We の領域か臨界值〜臨界值 +0.2 の非常に初期の非定常流にお いては, 流れに定常流の領域と非定常流の領域とが混在する. 非定常流初期の可視化実験結果(図 13)では, 図 13(a)だけ見 れば流れ全体が非定常流であるように見えるが, 図 13(b)から写 真の左上が非定常流の領域, 右下が定常流の領域と混在して いる樣子がよく分かる.图 13 は $0.2 \mathrm{wt} \% \mathrm{PAA}$ 水溶液を用いた可 視化実験結果であるが, $0.5 \mathrm{wt} \% \mathrm{PAA}$ 水溶液についても同樣の 


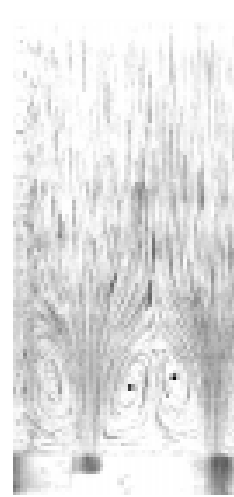

(a)

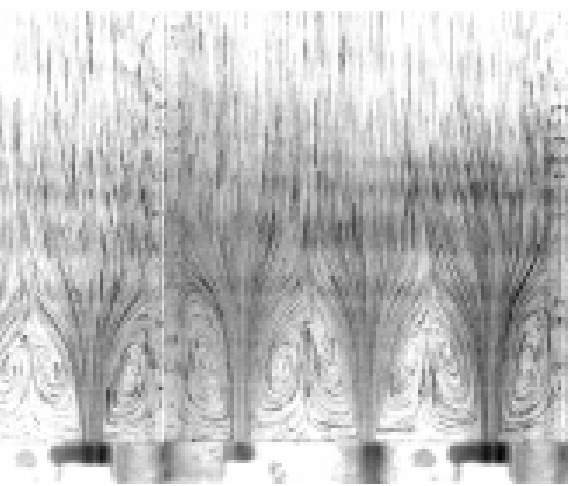

(b)

Fig.12 Location of vortex centers in a pair of lip vortex for the $0.2 \mathrm{wt} \%$ aqueous solution of PAA through a multi-hole three-by-three contraction (dimensionless pitch 8); (a): $R e=0.392, W e=2.01$, (b): $R e=0.694, W e=2.34$.

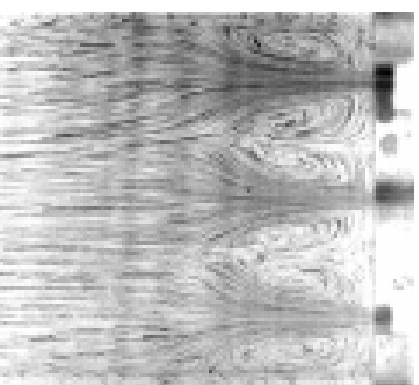

(a)

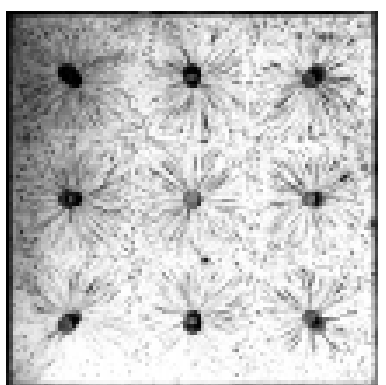

(b)
Fig.13 Flow patterns at the onset of unsteady flow for the $0.2 \mathrm{wt} \%$ aqueous solution of PAA through a multi-hole three-by-three contraction (dimensionless pitch 8); $R e=0.797, W e=2.41$.

現象が見られた。

\section{3 非定常流 \\ 40301 流れ構造}

図 14,15 は $0.2 \mathrm{wt} \% \mathrm{PAA}$ 水溶液を用い,無次元ピッチ 4 ,縮 小管数 9 の流路における非定常流を 15 秒間隔で (a) (d)へと 連続撮影した結果である.図 14 より中央の主流を含む 3 本の主 流が外側に膨らんだり,中心に近づいたりといった動作を繰り返 していることが分かる.また図 15 より中央にあるlip vortexが上下， 左右の渦の隙間に食い込む樣子が分かる.图 15 では矢印で示 すように,左右の渦の隙間へ食い込んでいたlip vortexが,上下 の隙間へと食い込み位置を変えて行〈樣子が見られる.さらにこ の連続撮影により,光の变動周期が約 $45 \mathrm{~s}$ であることが分かった . $0.5 \mathrm{wt} \% \mathrm{PAA}$ 水溶液についても同樣の実験を行い, $0.2 \mathrm{wt} \% \mathrm{PAA}$ 水溶液の場合と同樣の流れ構造, 周期的変動を示すことが確 認された。

無次元ピツチ 4 ,縮小管数 25 の流路についても同樣に,非定 常流における連続撮影を行ったが, $0.2 \mathrm{wt} \% \mathrm{PAA}$ 水溶液および $0.5 \mathrm{wt} \% \mathrm{PAA}$ 水溶液いずれについても, 明確な流れ構造のパタ ーンや周期的な変動は観察されなかった .

無次元ピツチ 8 ,縮小管数 9 の流路の場合，完全に非定常流

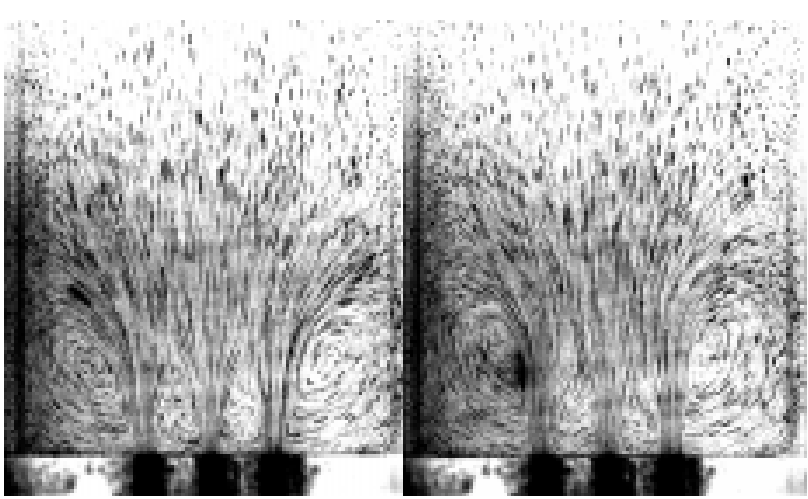

(a)

(b)

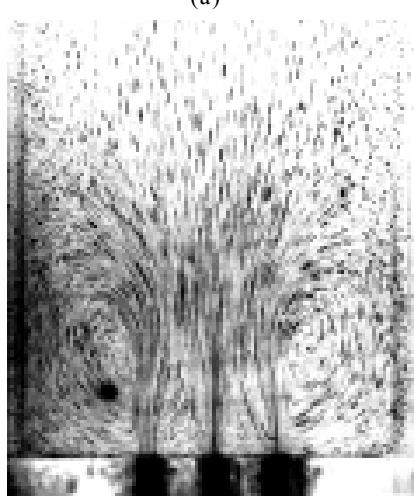

(c)

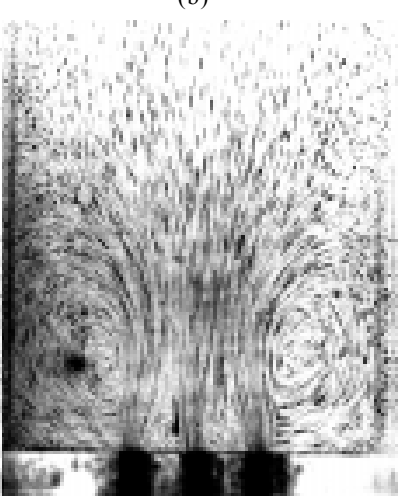

(d)
Fig.14 Consecutive photographs of the unsteady flow for the $0.2 \mathrm{wt} \%$ aqueous solution of PAA through a multi-hole three-by-three contraction (dimensionless pitch 4); (a) (d): $R e=1.22, W e=2.75$.

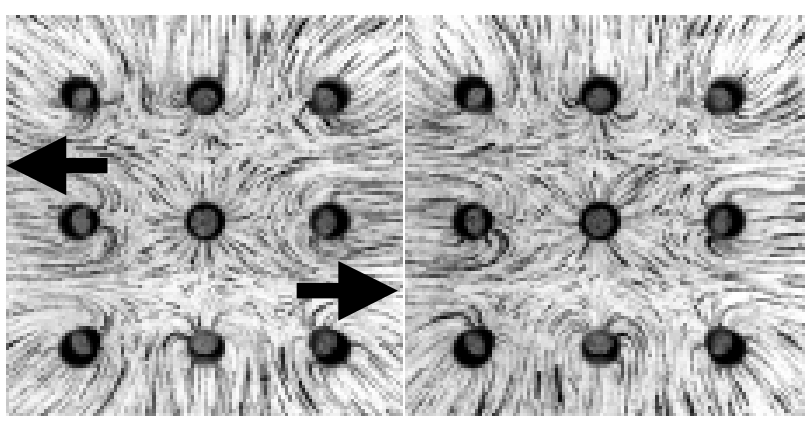

(a)

(b)

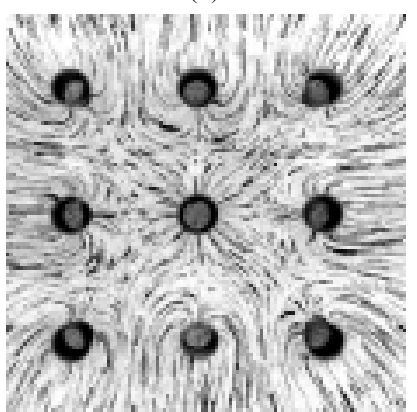

(c)

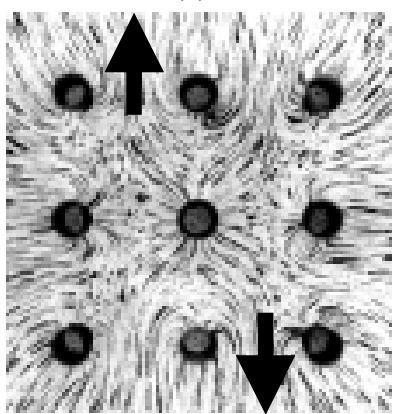

(d)
Fig. 15 Consecutive photographs of the unsteady flow near the contraction plane for the $0.2 \mathrm{wt} \%$ aqueous solution of PAA through a multi-hole three-by-three contraction (dimensionless pitch 4); (a) (d): $R e=1.27, W e=2.71$. 


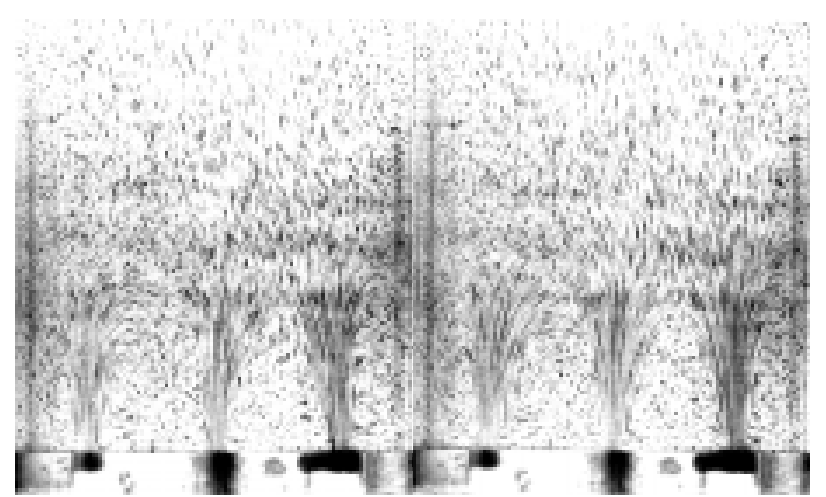

(a)

(b)

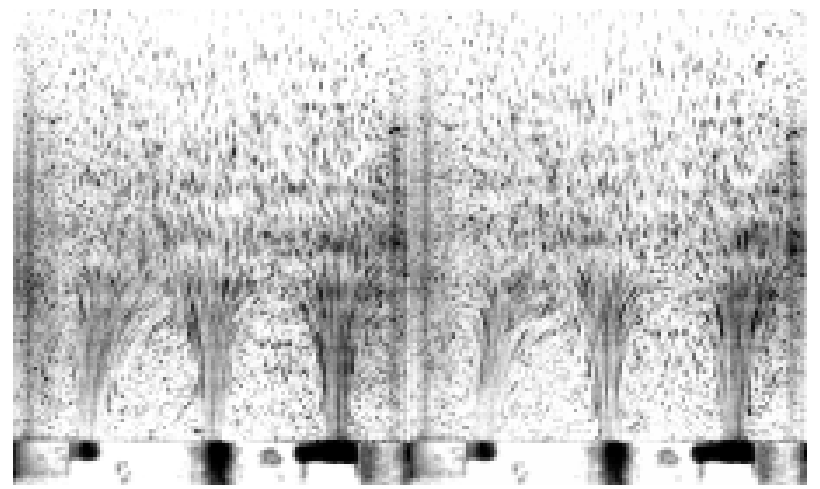

(c)

(d)

Fig.16 Consecutive photographs of the unsteady flow for the $0.2 \mathrm{wt} \%$ aqueous solution of PAA through a multi-hole three-by-three contraction (dimensionless pitch 8); (a) (d): $R e=1.08, W e=2.64$.
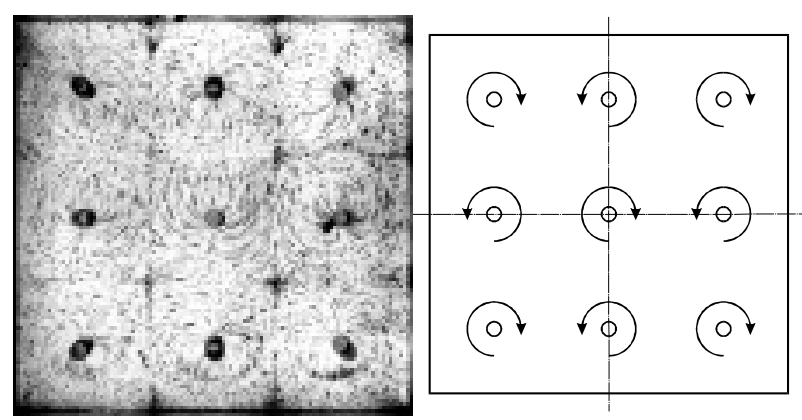

Fig.17 A flow pattern of the unsteady flow and illustration of the spiraling flows for the $0.2 \mathrm{wt} \%$ aqueous solution of PAA through a multi-hole three-by-three contraction (dimensionless pitch 8).

へ遷移した後は溶液の濃度により異なった流れ構造を示す.図 16 は $0.2 \mathrm{wt} \% \mathrm{PAA}$ 水溶液を用い 15 秒間隔で非定常流の連続 撮影を行った結果である.この非定常流では縮小管の間にある $2 つ の$ lip vortex の領域が交互に成長と収縮を繰り返す現象が 見られる.図 16 では左側の渦が収縮すると同時に,右側の渦が 成長していく樣子が確認できる.また縮小面近傍の連続撮影に より,各縮小管まわりの渦が旋回していることが分かった.すなわ ち各縮小管に流入する9 本の主流は spiral flow であると考えら

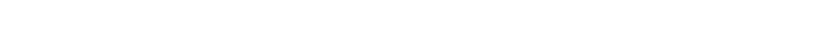
するのではなく,隣同士の渦との接点において運動の向きを一 致させるよう, 図 17 のイラストに示す方向に旋回していることも確

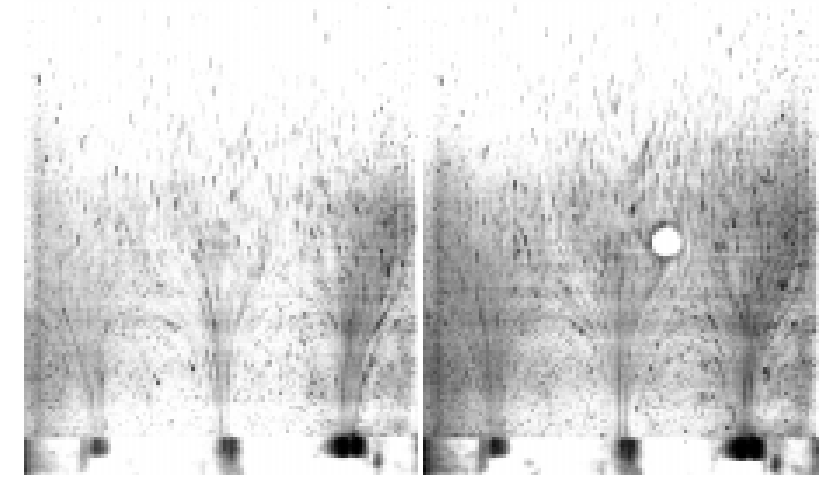

(a)

(b)

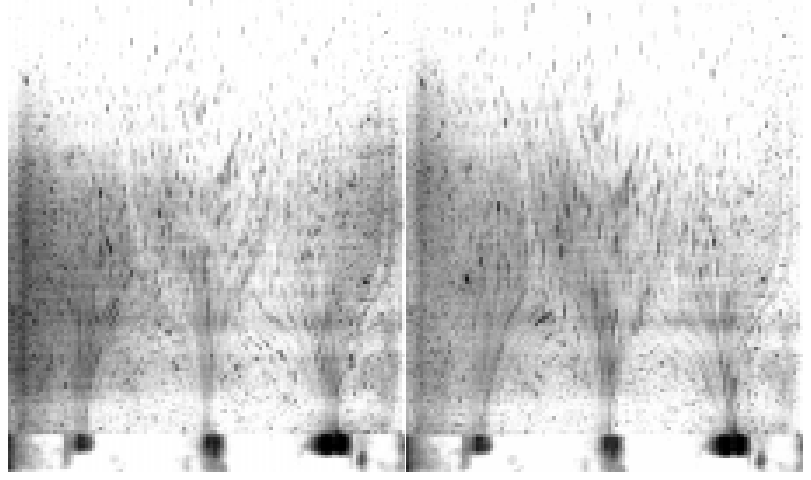

(c)

(d)

Fig.18 Consecutive photographs of the unsteady flow for the $0.5 \mathrm{wt} \%$ aqueous solution of PAA through a multi-hole three-by-three contraction (dimensionless pitch 8); (a) (d): $R e=0.136, W e=2.70$.

認できた .

$0.5 \mathrm{wt} \% \mathrm{PAA}$ 水溶液における非定常流の連続撮影結果を図 18 に示す $.0 .5 \mathrm{wt} \% \mathrm{PAA}$ 水溶液の場合,縮小管の間にある lip vortex は $0.2 \mathrm{wt} \% \mathrm{PAA}$ 水溶液のときのよう交互に成長, 収縮を 繰り返すのではなく,同時に成長,収縮を行っている.主流に注 目すると,3 本の主流は渦の変動に伴い, 外側に膨らんだり中央 に集まったりを繰り返していることが分かる.すなわちこの流れは 無次元ピツチ 4 ,縮小管数 9 の流路での非定常流に非常によく 似ている.残念ながら縮小面近傍での撮影結果では, 渦内の流 速が小さすぎるため流れが分からなかったが,中央の lip vortex は上下,左右へと交互に成長を繰り返していると予想される.

\section{2 流速変動}

LDV を用いて非定常流の流速を測定した .測定点は各流路 とも縮小面近傍の $\left(x / R_{d}, y / R_{d}, z / R_{d}\right)=(0,0,3)$ とし, 流速変動 を明らかにするため, 測定周波数を $5 \mathrm{~Hz}$, 測定時間を $210 \mathrm{~s}$ とし た.また流速データは高速 Fourier 変換を行い,変動の周期性 についても調べた.この結果を図 19 に示す .

無次元ピッチ 4 ,縮小管数 9 の流路では $R e=0.33, W e=1.9$ を 越えたあたりから流速に周期的変動(周波数 f)が見られ，さらに ワイセンベルク数が増加すると $0.5 f, 1.5 f$ が出現する.前述の可 視化実験結果(図 15)では非定常流の变動周期が約 45s, 周波 


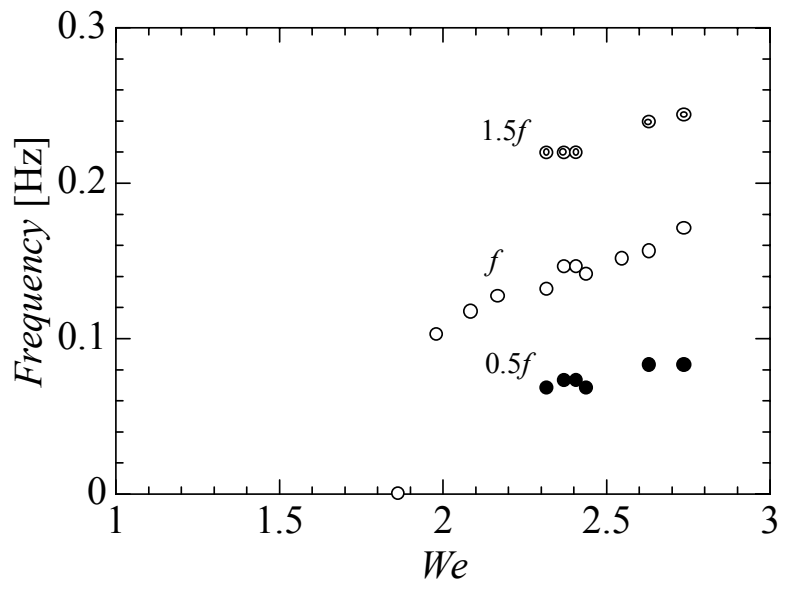

(a) Multi-hole three-by-three contraction (dimensionless pitch 4)

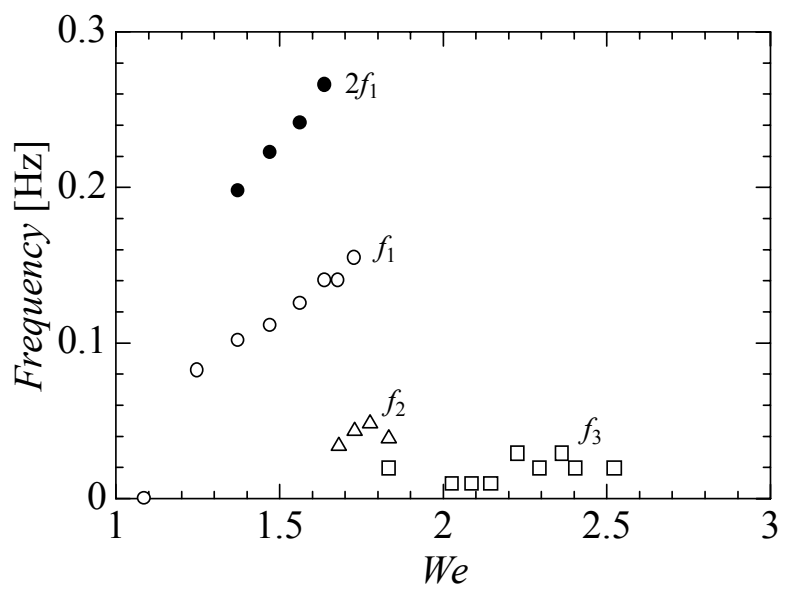

(b) Multi-hole five-by-five contraction (dimensionless pitch 4)

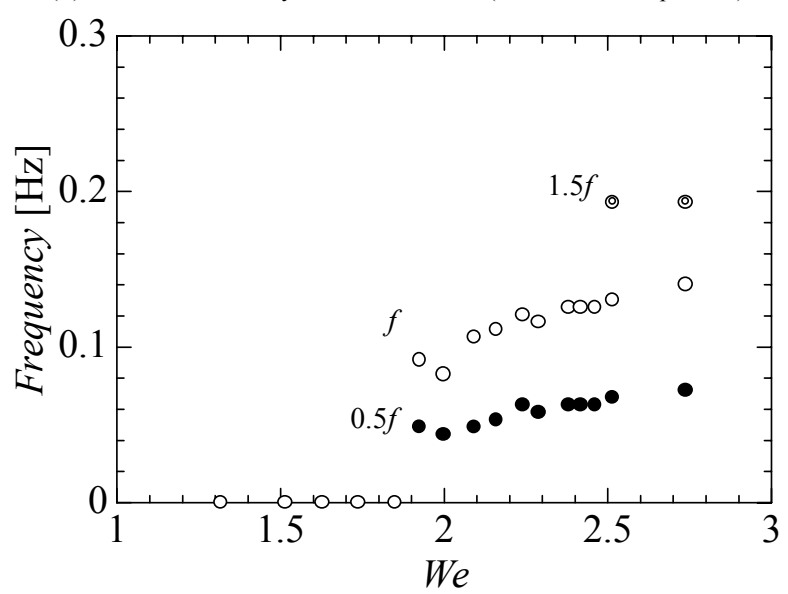

(c) Multi-hole three-by-three contraction (dimensionless pitch 8)

Fig.19 Frequency of oscillations in the velocity at the position of $\left(x / R_{d}, y / R_{d}, z / R_{d}\right)=(0,0,3)$ for the $0.2 \mathrm{wt} \%$ aqueous solution of PAA.

数にすると約 $0.022 \mathrm{~Hz}$ となるが,いずれの周波数もこれには一致 しない.LDV ではあくまでも主流の軸方向流速成分の変動を測 定しているため,流れ全体の变動とは必ずしも一致しないと考え られる。

無次元ピツチ 4 ,縮小管数 25 の流路では $R e=0.065, W e=$
1.2 を越えたあた叫ら $f_{1}$ が発生する.表 |に示す非定常流への 臨界点に達すると $2 f_{1}$ か現れ，しばらくは $f_{1}, 2 f_{1}$ の共存状態か続 〈. $R e=0.22, W e=1.7$ 付近ではさらに周波数の低い $f_{2}$ が出現し， これに伴い, $f_{1}, 2 f_{1}$ は減衰し,消失する.Re $>0.30, W e>1.8$ にな ると $f_{3}$ が出現する.この領域での可視化実験結果では,明確な 非定常流の構造や変動のパターンは観察されなかったが,主流 は明確に周期的変動を示していることが明らかになった。

無次元ピツチ 8 ,縮小管数 9 の流路では無次元ピツチ 4 ,縮 小管数 9 の流路と同樣, $R e=0.34, W e=1.9$ を越えたあたいから 周波数ピークが見られる.初期の段階から $f$ と $0.5 f$ の共存が見ら れるが, $1.5 f$ は $R e>0.95$,We $>2.5$ にならないと出現しない.この 流路の場合も,可視化実験により明確な非定常流の構造が観 察されているが,光の変動周期と LDV における周波数ピークと は必ずしも一致しないと考えられる。

このよう縮小管数 9 の流路では無次元ピツチにかかわらず， $0.5 f, f, 1.5 f$ の周波数ピークが発生し,縮小管数 25 の流路では $f_{1}, 2 f_{1}$ が発生する.すなわち変動の周波数特性は縮小管数によ って決まるといえる.またすべての流路において周波数ピークは 非定常流への臨界点よりWe $\approx 0.2$ 程度小さいところから出現し， 产の後ワイセンベルク数の増加に伴い増大する.さらにパワース ペクトルの振幅は低い周波数ほど大きくなるという傾向を示す．

\section{5. 結 言}

本研究では,複数の円孔急縮小部を有する 3 種類の流路を 用い,可視化実験および LDVによる流速測定により,定常流か ら非定常流に至るまでの流れ構造を調べた。乥の結果定常流，

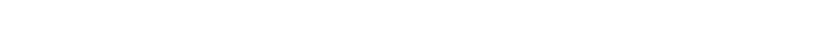
縮小管数, 無次元ピッチ, 溶液の濃度に依存していることか明ら かになった。

定常流における流れ構造は,縮小管数や溶液の濃度には 依存せず，無次元ピツチによって分類することができる.したがっ て縮小管数 9 の流路について実験を行えば, 同じ無次元ピツチ でさらに縮小管数の多い流路についても容易に流れ構造を予 測することができる.

定常流から非定常流入遷移する臨界ワイセンベルク数は縮 小管数と容液の濃度に依存して決まり,縮小管数が多いほど小 さ〈なる.さらに全体的に臨界レイノルス数は小さく $(R e<1)$ ，すな わち慣性の影響がさいことから,この原因は White と Kondo ${ }^{7)}$ が伸長応力に関連付けて提唱したstress-relief mechanismに基 づいて考えることができる.PAA 水溶液は伸長速度か増大する につれ，伸長粘度が増加する tension-thickening 性を有してい る.このため伸長速度か増大すると, 伸長応力はニュート流体 に比べ急激に増大することになる.しかし粘弾性流体は，この伸 長応力の增大を押さえるよう流れる、すなわち流量增加ととも に伸長応力が増大することになるが, 渦の成長により伸長速度 の増大が押さえられるため，伸長応力の増大を抑制することがで 
きる.単一の縮小管を有する流路では縮小面の面積が広〈渦が 大き増大することができるが,縮小管数が増えるにつれ，縮小 面の面積が小さくなりさらに複数の主流により渦が分割される.こ のため渦の成長が抑制されより低いワイセンベルク数で非定常 流に遷移する.さらに溶液の濃度が高くなると,同じ伸長速度に 対し伸長粘度がより大きくなるため,臨界ワイセンベルク数はさら に低くなる(しかしながら $0.5 \mathrm{wt} \% \mathrm{PAA}$ 水溶液における縮小管数 25 の流路にはこの考察が当てはまらず,現時点では未解決であ る) .

非定常流になると,縮小管数，無次元ピツチ，溶液の濃度す べてに依存して流れ構造は大き〈変わる.これは各縮小管に流 出する主流同士の相互干渉の度合いによって決まるものと考え られる.主流同士の相互干渉が非常に強い無次元ピツチ 4 ,縮 小管数 25 の流路の場合 $, 0.2 \mathrm{wt} \%, 0.5 \mathrm{wt} \% \mathrm{PAA}$ 水溶液ともに， 明確な流れ構造や周期的変動は観察されない.無次元ピツチ 4 ， 縮小管数 9 の流路および無次元ピツチ 8 ，縮小管数 9 の流路に $0.5 \mathrm{wt} \% \mathrm{PAA}$ 水溶液を流した場合は,主流同士の相互干渉も中 程度となり,主流は外側に膨らんだり中心に近づいたりを繰り返 す.縮小管同士の間隔が広〈(無次元ピツチ 8$)$, 溶液の濃度も 薄い $(0.2 \mathrm{wt} \% \mathrm{PAA})$ 場合は主流同士の相互干渉は小さくなり,主 流は spiraling flow となる.さらに LDV により非定常流における 主流の流速変動を測定した結果, 主流における変動の周波数 特性は,縮小管数によって分類できることが分かった .

\section{参考文献}

1) Boger DV, Hur DU, Binnington RJ, J Non-Newtonian Fluid Mech, 20, 31(1986).

2) Chiba K, Tanaka S, Nakamura K, J Non- Newtonian Fluid Mech, 42, 315(1992).

3) 中 雄一, 千葉 訓司, 中村喜代次, 日本レオロジー学会 誌, 26, 41(1998)

4) Cable PJ, Boger DV, AIChE J, 24, 869(1978).
5) Cable PJ, Boger DV, AIChE J, 24, 992(1978).

6) Cable PJ, Boger DV, AIChE J, 25, 152(1979).

7) White JL, Kondo A, J Non- Newtonian Fluid Mech, 3, 41(1977/ 1978).

8) White SA, Baird DG, J. of Non-Newtonian Fluid Mech., 20, 93(1986).

9) 森 教安, 中村 喜代次, Walters K, 繊維機械学会論文 集, 42, T179(1989).

$10)$ Bulters MJH, Meijer HEH, J Non-Newtonian Fluid Mech, 38, 43(1990).

11) Evans RE, Walters K, J Non-Newtonian Fluid Mech, 32, 95(1989).

12) Lawler JV, Muller SJ, Brown RA, Armstrong RC, J NonNewtonian Fluid Mech, 20, 51(1986).

13) McKinley GH, Raiford WP, Brown RA, Armstrong RC, J Fluid Mech, 223, 411(1991).

14) 中村 喜代次, 森 教安, 松村 賢治, 日本機械学会論文 集, 63, 1264(1997).

15) 中 雄一, 千葉 訓司, 中村 喜代次, 日本機械学会論文 集, 64, 2019(1998) .

16) Koelling KW, Prud'homme RK, Rheol Acta, 30, 511(1991).

17) Tanner RI, "Engineering Rheology", Clarendon Press, p354(1988).

18) Barnes HA, Hutton JF, Walters K, "An Introduction to Rheology”, Elsevier, p109(1989).

19) Ferguson J, Hudson NE, J Non-Newtonian Fluid Mech, 52, 121(1994).

20 ) Binding DM, Maia J, Walters K, J Non-Newtonian Fluid Mech, 52, 137(1994).

21) 丹慶勝市, 奥村 晴彦, 佐藤 俊朗, 小林 誠, ”Numerical Recipes in C(日本語版)”, 技術評論社, p379(1993). 